\title{
An oral reading of Romans 8:31-34
}

B E Shields ${ }^{1}$

(Emmanuel School of Religion, Tennessee, U S A)

\section{ABSTRACT}

\section{An oral reading of Romans 8:31-34}

This article introduces the reader to the study of oral communication in primarily oral cultures and its application to biblical studies and then goes on to illustrate the value of such study by looking at Romans 8:31-34 from the vantage point of its signs of orality. Such a study should open us to new insights into texts and also lead us to helpful understandings of preaching in our own cultures.

\section{ORALITY AND THE NEW TESTAMENT}

Since 1960 the people involved in the discipline of oral tradition studies have been analyzing systematically the process and results of oral composition and transmission of various types of human communication in many different cultures, both ancient and contemporary $^{2}$. The publication, in 1960, of Albert Lord's The Singer of Tales and the steady stream since then of studies of oral composition in both living traditions and ancient artifacts have established this discipline in the arena of academic studies. It is only recently that the modern methods of oral traditionists have begun to be applied to the biblical documents in order to describe the early process of their transmission by means of careful study of how oral traditions work in a primarily oral culture (Culley 1986:30-65).

The work of scholars of orality has made many of us biblical scholars aware of the history of human communication as we attempt to study our texts in their historical contexts. Only in this way can we fully appreciate the forms of communication we find in the written record of human communication in our Bible. And only as we become cognizant of the characteristics of communication in a

1 Research Associate, Prof C J A Vos, Department of Practical Theology, University of Pretoria.

2 Much of the material in these first pages is adapted from chapters in my book, From the Housetops: Preaching in the Early Church and Today (St. Louis: Chalice Press, 2000). 
primarily oral culture can we begin to recognize the challenge we who are primarily literate have in understanding the ancient texts.

The ages of the production of both testaments, as well as the first four hundred years in the life of the church, were characterized by what Walter Ong has been calling "primary orality" (see Ong 1982:31-77). By this he describes cultures which, even in the presence of writing, remain for the most important kinds of communication dependent on the spoken and heard word. The progress of the development of means of communication had been very slow for the first 4,000,000 years or so of human history. By whatever process human speech developed, for several millennia communication was confined to direct speech, supplemented by gestures, fires, drums, and horns. Early forms of pictorial representation of things and events appear to have been developed in all ancient cultures. Chirographic writing as we know it seems to have been introduced first in Sumer around 3,500 BCE, with the phonetic alphabet being developed in Phoenicia around 800 BCE. This gave people a way to represent sounds instead of just objects and events. Obviously hand copying made any mass communication very slow and labor-intensive.

The first practical mass production of literature became possible with the invention of block printing, which appeared in Rome around $131 \mathrm{CE}$. and in Asia about 3 centuries later (see Fore 1990:34-35). Ong's argument is convincing that it was only with the development of moveable type printing by Gutenberg in midfifteenth century Germany that the written word could become common enough to encourage a large enough percentage of the population to learn to read and write that we could characterize a culture as primarily literate (Ong 1967:47ff).

It is understandable, then, that Martin Luther appears, with all his learning, to have remained basically an oral person, while one generation later John Calvin would view the written word as the primary guarantee of orthodoxy. In many ways Luther seems to have been a modern thinker, and he used the printing press to great advantage; but he appears to have retained the criterion of the oral regula fidei, which he inherited from the medieval church, while Calvin was guided more by the Renaissance concern for ancient texts (cf. Graham 1987:141-154). 
The European Enlightenment of the seventeenth and eighteenth centuries was the source of the next impetus toward dependence on the written word in western civilization. Our world-view and thought patterns are so determined by this culture of literacy that it is difficult for us even to recognize it, much less analyze it. Like the air we breathe, we take it for granted until somebody calls our attention to it. However, the rapid changes in communication at the end of the twentieth century have captured our attention. Terms like "modem", "baud", and "E-mail" have become commonplace (Oddly enough the word "commonplace" is a term from oral education). Those of us who did not grow up getting most of our information about the world from television and computers, but rather from books and newspapers, often find ourselves a bit dizzy in today's world. Being involved in such a shift should make it somewhat easier for us to understand that a similar shift happened, although much more slowly, in the change from primary orality to primary literacy.

This paradigm change has made it very difficult for biblical scholars to escape our own literate ways of thinking and analyzing texts. The early form critics were aware that they were actually pursuing oral forms, but they seem not to have been able to evaluate those forms according to oral principles. When Werner Kelber's ground-breaking 1983 work The Oral and the Written Gospel: The Hermeneutics of Speaking and Writing in the Synoptic Tradition, Mark, Paul, and $Q$ was published scholars were puzzled by it. Some accepted it uncritically and others either rejected it or ignored it. Since then it has had a profound impact on many of us, even though most scholars have criticisms of it. In fact, in the second edition Kelber (1997) himself has softened some of his positions in a new introduction.

Kelber's work has spawned a working group in the Society of Biblical Literature called The Bible in Ancient and Modern Media. Two volumes of Semeia (Silberman 1987; Dewey 1994) have been devoted to the ongoing discussion in this group of the application of orality studies to the Bible. In the 2003 meeting of the SBL, a surprising number of presentations focused on or referred to oral composition issues. A consensus seems to be in the making that the study of biblical literature must take these disciplines seriously and begin to apply the methods of orality studies to texts of both the Hebrew and the Christian scriptures. 
This application is especially appropriate to Paul's letters, since

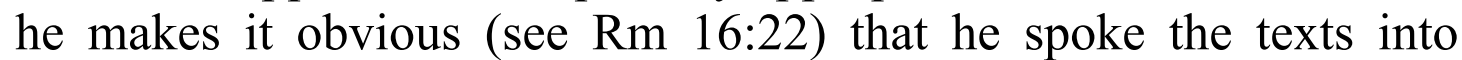
being - i.e. he dictated to a scribe ${ }^{3}$. This is evidence enough that the letters were composed orally (not carefully inscribed by the author in the quiet of his study). However, there is more. A quick look at Romans should be enough. Statements like 1:3-4 (“...who was descended from David according to the flesh and was declared to be Son of God with power according to the spirit of holiness by the resurrection from the dead, Jesus Christ our Lord") and 4:25 ("who was handed over for our trespasses and was raised for our justification") that have been identified as confessional statements can also be classified as oral formulae — statements spoken by believers in worship.

Bultmann himself identified the polemic question and answer style of so much of Romans as the diatribe rhetoric practiced by Cynic philosophers of Paul's time (Bultmann 1910) One finds a list in 1:29-31, with a self-evident rhyme in verse 31 , chiasms in 2:7-10 and 3:18-23, parallelisms in several places, including 4:5, 17, and 24 , and a catena in 5:3-5.

Romans 10 is especially full of oral markers (Dewey 1994: 109-127). Words like eudoki a (prayer) and mart ur w' (swear) in verses 1 and 2 would have oral communication referents in an oral culture; and of course verses 5-8 is Paul's play on the final speech of Moses in Deuteronomy 30, ending with the assurance that the saving word ( $r$ hma, always assumed as a spoken word in those times) is e $\mathrm{h}$ t w/ st omativs ou (in your mouth). Then verse 9 locates the confession that saves with the very same words: ej $t \mathbf{w} / \mathbf{s}$ t omat iv s ou. Beyond these orality markers is what Kelber calls the locus classicus of oral hermeneutics, verses 14-17 (Kelber 1997:149).

Here words of appealing, announcing, and speaking are teamed with words of hearing, culminating in verse 17: "So then, faith comes out of hearing and hearing by means of the expression of Christ." My translation here is an attempt to see meaning in the literal translation of the participles and to indicate that the use of r hma here (not I og o".) points to an actual speech event (Sprache-

3 See the greeting from the amanuensis, Tertius, in Romans 16:22, and Paul's statements about writing in his own hand in Galatians $6: 1$ and 1 Corinthians 16:21. 
reignis), not to a message about Christ. Words, especially in a primarily oral culture, are always sounds - not marks on a page or scroll.

After all, in the last analysis Paul was a preacher ${ }^{4}$. The search for markers of orality - formulaic expressions and repeated themes typical of Paul might indicate more than writing style. This orality approach might be a way to get a glimpse of his preaching, since it would be difficult for a practicing preacher not to fall into rhetorical patterns while dictating.

Paul's letters, however, have been analyzed in every conceivable way as literature. Their sources (inter-textuality) have been identified. Their structure has been mapped. Their writing style has been evaluated in an attempt to decide on authenticity. Their theology has been meticulously dissected. All of these disciplines have been helpful, but very rarely have their practitioners taken into account the oral rhetoric of their composition, or even the expectation that they would be read aloud to the congregations they are addressed to.

These literary and historical approaches, as important as they have been, have not helped to improve preaching and teaching on the congregational level as much as one would hope. That might be because preaching and teaching are oral forms, and preachers and teachers need help following the advice of Rudolf Bohren, "Die Texte sollen wieder werden, was sie waren, gesprochenes Wort, gepredigte Predigt" (Bohren 1980:148). Therefore, I want to present an analysis of Romans 8:31-34 as an oral composition to discover how we can preach from it.

One especially helpful insight from orality studies for this project is the discovery that in a primarily oral culture written orality is self-conscious orality (Bäuml 1984-1985:31-49) In other words Paul, in dictating his letters, would have been aware that the letters would carry at least as much personal authority as his presence would, and perhaps even more. Furthermore, the one reading these letters to the recipients was likely one of Paul's close confidants who, in many cases, was present during the dictation and so knew the tone and inflections of Paul's voice. Thus the reader was also (as

$4 \quad$ Luke (Acts 14:12) tells us that Paul was recognized as the Hermes of the duo Barnabas and Saul. 
is true with any oral reader) an interpreter, being free even to add explanatory statements occasionally during the presentation. As Joanna Dewey puts it, these are "writings in the service of orality"; (Dewey 1994:57) or in Antoinette Wire's words, the letter is a "speech-container" (Wire 1994:57). It is incumbent on us, then, to attempt to hear the speech underlying the text.

\section{THE TEXT AND REPRESENTATIVE TRANSLATIONS}

Tivouh ejoumen pro," taut a eijoJqeo;" uper hmwh, tiv kaqE hmwh; 32 of ge tou'idiou uibu' ouk ef eisato ajla; uper hmwh paut wn paredwken a uf on, $p$ w" ouj i;kai;s un a uf w/t a; pauta hmih carigetai; 33 tiv egkalesei kata; ekl ekt wh qeou' qeo; OJ dikaiwh:34 tiv of katakrinwÃ Cristo;", [Ehs ou"] o]ajoganwn, mall on de;ejerqeiv, of kaiveśt in ej dexia/t ou'qeou', of kai;ejt ugca nei uper hmwh.

31 What then are we to say about these things? If God is for us, who is against us?32 He who did not withhold his own Son, but gave him up for all of us, will he not with him also give us everything else?33 Who will bring any charge against God's elect? It is God who justifies.34 Who is to condemn? It is Christ Jesus, who died, yes, who was raised, who is at the right hand of God, who indeed intercedes for us. (NRSV)

31 What, then, shall we say in response to this? If God is for us, who can be against us? 32 He who did not spare his own Son, but gave him up for us all - how will he not also, along with him, graciously give us all things? 33 Who will bring any charge against those whom God has chosen? It is God who justifies. 34 Who is he that condemns? Christ Jesus, who died - more than that, who was raised to life - is at the right hand of God and is also interceding for us. (NIV)

31 Was wollen wir nun hierzu sagen? Ist Gott für uns, wer mag wider uns sein? 32 welcher auch seines eigenen Sohnes nicht hat verschonet, sondern hat ihn für uns mit ihm nicht alles schenken? 33 Wer will die Auserwählten Gottes beschuldigen? Gott ist hier, der da gerecht macht. 34 Wer will verdammen? Christus ist hier, der gestorben ist, ja vielmehr, der auch auferwecht ist, welcher ist zur Rechten Gottes und vertritt uns (Luther). 


\section{SOME EXEGETICAL OBSERVATIONS}

Verse 31 begins with a rhetorical question that heads the whole passage: Tivouh ejoumen prof" ta ut a; (What then are we to say to these things?) The reference is to the sufferings and deep inner pain felt by the Christian who at the same time is assured that everything is in God's hands. This is the preceding context. The immediate answer, of course, is another rhetorical question: eij of qeo;" uper hmwh, tiv kaqE hmwh; (If God be for us, who is against us?) This whole passage, verses $31 \mathrm{~b}-34$, has the form of a ring composition, with the opening statement (following the introductory question), eij of qeo," ujer hjwwh, pointing to the closing statement, of kai; ejt ugca nei uper hmwh (who also intercedes for us).

Verse 32 appears to emphasize the graciousness of God by using three different ways of saying give. ouk ef ei s a to (did not withold) states that the God who is for us doesn't withhold even the most precious commodity - the Son himself. P a r edwken (handed over) is the term Paul uses in 4:25 in reference to the crucifixion (paredogh).This God even hands over the Son to death. And cariset a (give freely) is the loving gift of everything, the gift of grace.

Note the neat parallelism in verses 33-34a, or as I see it, a little ring composition (Michel 1966:282). First we hear another rhetorical question: tiv egkalesei kata; eklekt wh qeou (Who shall register a charge against God's elect?) Paul replies in 33b-34 with qeo; of dikai wh (God the one justifying) — in a style similar to Isaiah 50:8, which reads (LXX): of i eggizei of dikaiwsa" me, tiv of krinomenow moi; ajtisthtw moi afna kai; tiv of krinomenov moi;egigatw moi. (He who vindicates me is near. Who will contend with me? Let us stand up together. Who are my adversaries? Let them confront me [NRSV]) This is followed by the end of the little ring — a matching rhetorical question: t it 0 J kat a krinwh; (Who is the one condemning?). This ring stands in the exact middle of the passage (verses 31-34). It includes a central confession of faith about God the justifier, and it ends with the question that introduces what Paul wants to say here about Christ. Paul has dealt with the gracious work of Christ in a number of different ways in Romans 1-7. He has used a variety of metaphors for the saving work of Christ and its effects. One can glimpse the 
variety in 3:21-26 and 5:1-11. Now he prepares to paint one more picture of the work of Christ.

Again he introduces his thought with a question: $t i v$ of kat a krinwh; This participle can be read as either present or future. Dunn22 translates it as a sort of timeless present: "Who is there to condemn?" Even if it is present, it must have a future aspect. Käsemann says (I think rightly), "Das Futur ist nicht eschatologisch, sondern logisch".23 Paul has begun this section (8:1) of the letter with the blanket statement, 0 uden a [a nuh katakrima toi" ej C ris t w' Ahs ou'. (There is therefore now no condemnation to those in Christ Jesus). Now he is ready to defend his claim. His defense is an oral masterpiece.

Who is to condemn? The next word is C rist o, [ J hs ou" "], followed by four descriptive statements. Paul's description of Christ and his work in this instance employs first two participles and then two relative pronoun clauses with finite verbs. There is nothing boring about his style here. The participles read $\boldsymbol{A}$ a poqanwn, ma I I on de;eger qei ${ }^{6}{ }^{6}$ (who died, but rather was raised), As a reply to Paul's question about condemning (judging), Christ is here, as in Acts 17:31, centrally involved in the process of the eschatological judgment.

The third Christological statement is of kaives $t$ in ej dexiay to u' qeou' (who also is at God's right hand). This appears to echo Psalm 110:1 (LXX, 109): Eipen oJkurio" t w/kuriw/mou K a qou ek dexiwh mou, ew" a q qw'tou,' ej qroul s ou upopodion t wh podwh s ou (The LORD says to my lord, "Sit at my right hand until I make your enemies your footstool" [NRSV]). Here we get a glimpse of the risen Lord in the position of power.

The fourth descriptive statement is the one that proclaims hope for the children of God: of kai; ejt ugcanei uper hmwh. This verb is related to that used of the Holy Spirit in verse 26, where the Spirit helps us in our praying. Here Christ helps us in the judgment. As Wilckens puts it, The Holy Spirit, in residence in our hearts by virtue of our baptism, shrinks the distance between us humans and God by translating our deepest prayers into terms appropriate for the

5 Many manuscripts include Jhs ou" here, and the evidence is relatively strong, although it could be influenced by the usage in $8: 1$.

6 Some manuscripts add ek nekr wh to the second participle, but that is likely a scribal addition. 
hearing of the almighty; while Christ, residing in the presence of God speaks a saving word on our behalf now and in the judgment (Wilkens 1980:174-175).

The present tense, however, could indicate that this is more than a hope for the eschaton. It looks as though Christ is also involved in intercession on our behalf in the present. Jewish thought already attributed intercession to angels or holy ones in the presence of $\mathrm{God}^{7}$. Whether or not there is a tradition in the background of this claim, Paul is certainly asserting a great consolation for those whose "sufferings of this present time" (verse 18) make them wonder whether or not the Christian faith is worth the trouble. For such people, rushing through the first three of these statements about Christ to get to Christ as Intercessor seems like rushing from Palm Sunday to Easter, forgetting the crucifixion. In doing so we miss the tension that communicates the deep significance.

If one reads it slowly, with a sense of rhythm - the timing of a preacher - one gets the impact of the statement. Reading it aloud draws attention to the rhyme scheme. Words ending in wh abound: uper hmwh...kaqfehmwh...uper hmwh...eklect wh... dikaiwh... kat akrinwh...apoqanwn...uper hmwh. In the center stands that little ring statement: a question beginning with $t i v$ comprises the first and last lines, with the strong affirmation qeo," of dika iwh in the middle; and each of the three lines ends with the wh sound. This is masterful oral communication.

Pausing between phrases emphasizes the oral rhetoric, and we might even imagine the performer of the piece in Rome (Phoebe, perhaps) inserting some explanatory statements, knowing the intent of Paul. Such oral reading takes us back to oral composition, giving us instead of shorthand (speed reading) the art of the orator that keeps the hearer in suspense as long as possible.

7 See 1 Enoch 13:4, where Enoch promises to intercede for the fallen angel(s); although in 14:1-4 it appears that he was not successful. 
The text slowly now:

Tivoun ejoumen pro," t a ut a

eijoJqeo;" uper hmwh,

tiv kaq/EhJnwh

of ge tou'idiou uibu'ouk ef eis at 0

a) I a;uper hmwh pant wn paredwken a uf on,

pw" ouf $i ; k a i ; s$ un a uf w/t a;

paut a hmih carisetai

tiv egkal esei kat a;ekl ekt wh qeou'

qeo," oldikaiwh:

tiv ojkat akrinwh

Crist o," [Ahs ou"]

oJa p oqa nwa,

mall on de;ejerqeiv,

of kaiveśt in ej dexia/t ou'qeou',

of kai;ejt ugcanei uper hmwh.
What then do we say to this?

If God be for us

Who is against us?

The one who did not withhold his own Son

But handed him over for us,

How shall he not also with him give us everything?

Who shall register a charge against God's called ones?

God is the one justifying;

Who is the one condemning?

Christ, [the only one worthy. He has the right to condemn.]

The one dying, [who suffered the wages of sin without earning them. He has a reason to condemn.]

The one, however, rising, [who is alive. He has the ability to condemn.]

Who also is at God's right hand, [who is in the seat of power. He has the authority to condemn.]

Who also intercedes for us. [who should be our prosecuting attorney, but who is actually our defense attorney.]

\section{CONCLUSION}

If one is to fill in the gaps with more information from the life of Jesus and the backgrounds in Jewish literature, add a few contemporary illustrations, and you have a tremendous pastoral 
sermon. It has personal interest, suspense, nice pacing, and a twist at the end. More important to me is the insight it gives to Paul's oral communication. Paul was not only a great theological thinker, he was also in tune with the reality of the life of faith - a reality that was hardly progress from victory to victory. He knew the difficulties of life; but he was simultaneously absolutely convinced that God was working out the purpose for all creation and therefore could be trusted to make "all things work together for good for those who love God, who are called according to his purpose" (8:28 NRSV).

The reason I chose Romans 8:31-34 to study in this way is that these four verses often are overshadowed by the attention give to $8: 28$ and 8:35-39. The theology of the former and the beauty of the latter I cannot deny. However, the centrality of verses 31-34 to the gospel Paul was dedicated to proclaim should draw us back to it often but slowly.

\section{Consulted literature}

Bäuml, F 2001. "Medieval Texts and the Two theories of Oral-Formulaic Composition: A Proposal for a Third Theory", New Literary History 16 (1984-1985), 31-49, in Martin S. Jaffee, Torah in the Mouth, Oxford: Oxford University Press, 5-6.

Bohren, R 1980. Predigtlehre. München: Chr. Kaiser Verlag.

Bultmann, R 1910. Der Stil der paulinischen Predigt und die kynischstische Diatribe, Göttingen: Vandenhoek und Ruprecht.

Culley, R 1986. "Oral Tradition and Biblical Studies", in Oral Tradition 1/1: 3065.

Dewey, A J 1994. “A Re-Hearing of Rom 10:1-15,” Semeia 65: 109-127.

Dewey, J 1994. "Textuality in an Oral Culture: A Survey of the Pauline Traditions", Semeia 65: 37-65.

Dewey, J (ed.) 1995. Semeia 65. Atlanta: Scholars Press.

Dunn, J D G 1988. Romans 1-8, Word Biblical Commentary. Dallas: Word Books.

Foley, J M 1985. Oral Formulaic Theory and Research: An Introduction and Annotated Bibliography. New York: Garland Publishing, Inc.

Fore, W F 1990. Mythmakers: Gospel, Culture and the Media. New York: Friendship Press.

Graham, W A 1987. Beyond The Written Word: Oral Aspects of Scripture in the History of Religion. Cambridge: Cambridge University Press.

Havelock, E A 1963. Preface to Plato. Cambridge, Mass.: Harvard University Press. 
Jaffee, M S 2001. Torah in the Mouth: Writing and Oral Tradition in Palestinian Judaism 200 BCE-400CE. Oxford: Oxford University Press.

Käsemann, E 1974. An Die Römer, 3. überarbeitete Auflage, Handbuch Zum Neuen Testament 8a. Tübingen: J.C.B. Mohr (Paul Siebeck).

Kelber, W H 1983. The Oral and the Written Gospel. Philadelphia: Fortress Press.

-, 1997. The Oral and the Written Gospel ( $2^{\text {nd }}$ ed.). Bloomington: Indiana University Press.

Lord, A B 1960. The Singer of Tales. Cambridge, MA: Harvard University Press.

Michel, O 1966. Der Brief An Die Römer, 5. bearbeitete Auflage, KritischeExegetischer Kommentar Über das Neue Testament IV - 14. Göttingen: Vandenhoeck \& Ruprecht.

Minchin, E 1996. "The Performance of Lists and Catalogues in the Homeric Epics", in Voice into Text: Orality and Literacy in Ancient Greece, ed. Ian Worthington. Leiden: E.J. Brill, 1996, 3-20.

Ong, W J 1967. The Presence of the Word: Some Prolegomena for Cultural and Religious History. Minneapolis: University of Minnesota Press, $47 \mathrm{ff}$.

-, 1982. "Some Psychodynamics of Orality" in: Orality and Literacy: The Technologizing of the Word: London and Yew York: Mehuen, 31-77.

-, 1992. "Knowledge in Time", in Faith and Contexts Volume One: Selected Essays and Studies 1952-1991, ed. Thomas J. Farrell and Paul A Soukup. Atlanta: Scholars Press, 1992, 127-153.

Shields, B E 2000. From The Housetops: Preaching in the Early Church and Today. St. Louis: Chalice Press.

Silberman, L H (ed.) 1987. Semeia 39. Decatur, GA: Scholars Press.

Stuhlmacher, P 1989. Der Brief and die Römer. NTD 6. Göttingen: Vandenhoeck \& Ruprecht.

Wilckens, U 1980. Der Brief An Die Römer (Röm 6-11) Evangelisch-Katholischer Kommentar zum Neuen Testament VI/2. Zürich: Benziger/ Neukirchener Verlag.

Wire 1994. "Performance, Politics and Power: A Response". Semeia 65: $129 f$.

Worthington, I 1996. "Greek Oratory and the Oral/Literate Division", in Voice into Text: Orality and Literacy in Ancient Greece, ed. Ian Worthington, Leiden: E.J. Brill, 1996, 165-178. 